April 2013

\title{
Valuing Students' Cultural Experiences and Linguistic Abilities In the Classroom
}

\author{
Tynisha Meidl \\ St. Norbert College, tynisha.meidl@snc.edu \\ Christopher Meidl \\ St. Norbert College
}

Follow this and additional works at: https://digitalscholarship.unlv.edu/jpme

\section{Repository Citation}

Meidl, Tynisha and Meidl, Christopher (2013) "Valuing Students' Cultural Experiences and Linguistic Abilities In the Classroom," Journal of Praxis in Multicultural Education: Vol. 7: No. 1, Article 5.

DOI: 10.9741/2161-2978.1064

Available at: https://digitalscholarship.unlv.edu/jpme/vol7/iss1/5

This Article is protected by copyright and/or related rights. It has been brought to you by Digital Scholarship@UNLV with permission from the rights-holder(s). You are free to use this Article in any way that is permitted by the copyright and related rights legislation that applies to your use. For other uses you need to obtain permission from the rights-holder(s) directly, unless additional rights are indicated by a Creative Commons license in the record and/ or on the work itself.

This Article has been accepted for inclusion in Journal of Praxis in Multicultural Education by an authorized administrator of Digital Scholarship@UNLV. For more information, please contact digitalscholarship@unlv.edu. 


\section{Introduction}

English Language Learners (ELL) and students represented in culturally diverse communities are the fastest growing groups in US public schools (Samway \& McKeon, 2007). In 2002, the U.S. Department of Education predicted that by 2010 minority populations will be the majority in public schools. Mainstream classrooms often struggle to meet the needs of Linguistically and Culturally Diverse (LCD) students, trying to connect instruction to students' linguistic backgrounds or cultural experiences (Darder, 1991). Mainstream classrooms, those taught by teachers who have not be specifically trained or certified to work with LCD student populations (Samway and McKeon, 2007), struggle to meet students' basic needs, while NCLB requires teachers to close the achievement gap by meeting Adequate Yearly Progress (AYP) on the state standardized tests with the subgroups within the school and district.

This article explores reasons why students' cultural experiences and linguistic abilities are not recognized in mainstream classrooms in an era of highstakes testing. The article will primarily draw on the works from Paulo Freire and Antonia Darder. The banking method of education will be explored with regards to standards based education and high-stakes testing, which are key components of current trends in American education.

Additionally, the article will peer into the role of teachers in meeting the needs of LCD student populations when they are often times presented with scripted or scripted curricula. The discussion will emphasize the deskilling and deprofessionalization of teachers as a form of oppression in which teachers are forced to export pedagogical practices without having the autonomy to adapt and reinvent them (Friere, 2005). The deskilling and deprofessionalization of teachers are tied to the lack of teacher autonomy in the approach and materials of the curriculum. National standards are translated into state standards and then relayed through curriculum materials, binders, and a scope and sequence that is geared to creating a common curriculum and a common set of learning experiences that are assessed on state tests (McLaren \& Farahmandpur, 2001). Unfortunately, the education of LCD students has become exercises of "drill and kill" and highly scripted instruction (Darder \& Torres, 2004). The teacher deskilling process not only dis-empowers teachers, but the curricular choices are limited and therefore often do not acknowledge the needs of LCD students. The deskilling and deprofessionalization of teachers is often seen in low performing schools where curriculum and materials are created and prepared in such a way that teachers are not given curricular autonomy or encouraged to shape and adapt curricula and classroom materials to support and address the needs of their LCD classroom through on-going professional development (Darder \& Torres, 2004).

Freire's notion of "false generosity" in an era of standards based instruction, where market forces are at work will be explored. Standards based 
instructions is believed to be the most effective way to raise educational standards and high-stakes testing is the most effective way to asses student achievement (McLaren \& Farahmandpur, 2001). False generosity serves to mask oppression by creating opportunities that appear to address issues, but permit injustice to continue. False generosity is seen in how "a system of merit is tied to high stakes testing, for example, the process of unequal privilege and entitlement is successfully camouflage under the guise of 'fair and equal' opportunity for all students" (Darder \& Torres, 2004, p. 92). Policymakers and others in positions of power dictate the standards and assess students to give the impression that everyone is achieving and the achievement gap is closing because now education is fair and equal.

In contrast, there are concerns that standards based instruction will result in punitive actions against the most disadvantaged students, resulting in LCD students not finishing high school (Owings \& Kaplan, 2001). Standards based reform is a way of perpetuating the standard quo while preserving systems that seek to privatize public education. The proposed cure for low student achievement and other social ills such as poverty, unemployment and the declining economy is standards and high-stakes testing (Owings \& Kaplan, 2001) rather than addressing the systems that perpetuate the social ills of society.

Finally, as a means to bring closure current literature will be used to demonstrate how teachers, despite hegemonic forces, can find ways to be autonomous and find pedagogical approaches that will address and meet the needs of their students within the standards based reform movement. This process will help teachers and their students to make connections with their cultural experiences and linguistic abilities and improve outcomes for all children.

\section{Banking Understood}

In Pedagogy of the Oppressed, Freire (2003) warns against the banking system of education. This concept of education describes a process where teachers make deposits of knowledge and information into minds of passive students where teachers are the depositors and students are the depositories (Freire, 2003). The banking concept of education constructs environments where teachers act upon the students and the students are acted upon (Freire, 2003). Yet, it is important to note that Freire's model of banking is an idealized type, but in practice educators may not fit this model exactly. This way of teaching reinforces attitudes of oppression and suppresses cultural voices in the classroom and society by implying the teachers' roles as keepers and distributors of knowledge while students don't know anything; privileging teachers to choose the content or "official" knowledge to be imparted upon the students. Educators in this system of education view themselves as possessors and imparters of knowledge where students are empty containers to be filled. Also, the banking concept of education permits teachers "not [to] question dominant mechanisms designed to produce 
power asymmetries along the lines of race, gender, class, culture and ethnicity" (Macedo, 2006). When educators bank they negate knowledge as the process of inquiry (Freire, 2003). This form of education makes students dependent on the teacher for their acquisition of knowledge (Darder, 1997) and do not present students with the skills that they need to construct their own knowledge.

\section{On False Generosity}

Businesses are feeding on the rhetoric of the failure of American public schools. Darder and Torres (2004) inform that businesses have an interest in public education in which they can improve education at no extra cost, in which they use scientific claims to respond to academic problems faced by LCD groups. Policies like high- stakes testing take on a very scientific approach "because they take science for the ultimate truth, outside of which nothing counts, believing that only science can produce certainty" (Freire, 2005, p. 15). Low test scores can quickly lead to blaming communities for failures. Communities such as lowincome families, African Americans, Hispanics, and second language learners, are under the assumption that success on the test will bring economic success, entrance into college, or a good job. This paternalistic way of setting up our educational system still seeks to privilege those in power. If standards are taught then students will achieve; presenting a sense of false generosity. Systemic changes are not made to address non-academic issues that play into academic failure such as living conditions, lack of highly-qualified teachers, poverty, and lack of adequate funding. Test scores and standards based learning are being used to mask other issue in American society.

Business leaders, particularly textbook companies, have strengthened their products, by aligning them to state standards, testing objectives, and by providing additional assessment materials. Standards are used to make decisions, create curricula, and determine the "pedagogical imperatives of the classroom," (Darder $\&$ Torres, 2004, p. 80) but they often neglect the cultural and linguistic needs of students. This builds on Freire's (2003) notion of false generosity. Businesses and those in power have a lack of faith in the ability of LCD student population to achieve in authentic ways, but believe a test will measure their achievement. According to Freire, false generosity is when an oppressor gives something to the oppressed without the intention of helping that person to become more free and self sufficient, but rather to continue to maintain control through a sense of dependency. High-stakes testing demonstrates that the vested interests of those in places of power, such as politicians, government officials, and businesses, reign. High stakes testing shifts the educational decisions from the classroom, schools, and districts and place increased authority at the state and federal level. Allington (2002) may argue that the increased authority is only at the federal level. Highstakes testing seeks to maintain the status quo by sorting students by achievement levels, ultimately setting up a system of winners and losers. Successful students 
from groups that are not traditionally successful on tests then become tokens. Those who are unsuccessful are seen as at fault, as is the classroom teacher. However, because of the way tests and curriculum is created, it is difficult to negotiate through the cultural ideologies of dominant discourses, leaving these students labeled as underperforming or "at-risk". Therefore, the needs of LCD students are not being met, which leads to underperformance.

\section{From Standards Based Reform to Scripted Curricula}

Unfortunately, in our current educational system, many teachers are being forced to engage in the banking model of education due to standards based educational reform effort. In some schools teachers do not get to choose their curriculum. NCLB requires that schools adopt curricula aligned to state standards. When teachers are not included in the curriculum adoption process or curriculum decision making, they are forced to plan and deliver a enact curriculum that may not be appropriate to meet the needs of their diverse population or permit opportunities for individualized instruction. "For many teachers, curriculum has become a prescribed set of academic standards, instructional pacing has become a race against a clock to cover the standards, and the sole goal of teaching has been reduced to raising student test scores on a single test" (Tomlinson, 2000, p. 7). Curriculum materials should be based on sound evidence that ensures students' ability to be proficient in academic content areas. However, scripted models often espouse a theory or a specific practice. Freire (2005) warns that "there is never only one theory, never only one practice" (p. 93). Teachers need the autonomy to modify the theories and practices they use in order to meet the diverse needs of their students.

Teachers should have an active voice, be involved in curriculum development, adapt curriculum, and adjust learning experiences and formative assessments so that each learner experiences success (Owings \& Kaplan, 2001). Teachers should use the planned curriculum to create lessons with the anticipation that students will learn. Unfortunately, some teachers are not given the autonomy to adjust instruction away from the planned curriculum because they are provided with scripted curriculum. This standardized approach to school curriculum gives teachers exact content to which they must adhere (Darder \& Torres, 2004). In many cases, teachers are held accountable for student performance on high-stakes test and should be encouraged and given the autonomy to engage in curriculum decision making and employ best practices to meet the needs of their students. Thus, teachers are encouraged to move beyond the melting-pot mentality and the "one-size-fits-all" approach that does not take differentiation based on language, culture, community, and social economic status into account (Darder, 1991).

Scripted as a form of teacher proof, curriculums are of concern because they negate the needs of LCD student populations. When teachers are required to use a scripted curriculum both "students and teachers, as subjects of classroom 
discourse who bring their personal stories and life experiences to bear on their teaching and learning, are systematically silenced by the need for the class to 'cover' a generic curriculum at a prescribed pace established by the state" (Darder $\&$ Torres, 2004, p.87). I am not suggesting that there shouldn't be any curriculum, but teachers should be permitted and expected to expand on the planned curriculum and adapt it to fit the needs of their students. Standards-based reform has led many schools to make curriculum align to state standards. As a result, some school districts are choosing scripted curriculum, thinking that it will help with raising test scores. This approach to curriculum planning employs banking methods to teach basic skills, with the assumption that students will score better on standardized tests (Darder \& Torres, 2004). Often, curriculum ignores the experiences and backgrounds of students from different linguistic and cultural groups, reflecting only European-American or mainstream culture (Delpit, 1996; Ladson-Billings, 1994; Nieto; 1999). Students are not learning to deconstruct the meanings of texts, their voices are silenced, and their linguistic abilities and cultural experiences are not acknowledged.

\section{Scripted Curriculum}

With the rise in state standards and accountability systems, teachers are finding it difficult to employ past teaching strategies while meeting the demands of ever changing curricular reforms and mandates from state and local education agencies. New teachers are leaving certification programs with the expectation that "the curriculum people will tell you what to teach" (Kayes \& Maranto, 2006, p. 41). With the rise in standards based educations, all teachers, regardless of experience, feel the pressure to meet standards and increase student achievement through the district's prescribed one-size-fits-all approach. The rise in scripted curriculum leaves those who "know their subjects well, who teach in ways that critically engage their students, and who want teaching to be linked to the realities of students' lives" (Darder \& Torres, 2004, p. 85) crippled and disturbed. These teachers are confined to the curricular demands of the school or district while they grapple with understanding the academic needs of LCD students.

Darder (1997) states that scripted curriculum "fails to acknowledge the creative potential of educators to grapple effectively with the multiplicity of contexts that they find in their classrooms and to shape environments according to the lived experiences and actual educational needs of their students" (p. 332). Scripted curriculum is a form of banking education and Freire and Darder would view it as problematic and oppressive. Teaching the standards through scripted curriculum demonstrates how schools are setting up structures that define what knowledge is of most worth. Teachers have always had to make choices about which forms of knowledge are more important due to the fact that they cannot teach everything in the nine months that they work with students. However, standards based reform in American public schools responds to critiques that 
schools need to prepare students with the knowledge and skills necessary for college or full-time employment (Owings \& Kaplan, 2001).

Standards suggest a "one-size-fits-all" approach. The curriculum is a prescribed set of academic standards (Tomlinson, 2000). This forces all students to become competent in the same content matter. This can be oppressive to the teacher because she or he does not have the flexibility or autonomy to create lessons that stimulate or engage students because standards based reform don't acknowledge the cultural and personal experiences. Kaplan and Owings (2001) assert that standards deprive students and teachers of a broad range of creative learning experiences.

Standards do not have to be oppressive if systems are set up so that learning is designed to foster instructional practices that allow for differentiation and personalization. As a result, I believe in quality instruction for LCD students, where instruction is continually adjusted to address the needs of the students. Standards based instruction does not "preclude the possibility of including the multiple perspectives in the curriculum" (Neito \& Bode, 2007, p. 26). Instead Nieto \& Bode (2007) call for a standards- conscious curriculum where the standards are a tool that still promotes a rigorous, demanding, and inspiring curriculum that can be creatively designed around the needs for the diverse student populations.

In many schools teachers are faced with scripted curriculum that disempowers, deskills, and de-professionalizes them (Darder \& Torres, 2004). This type of curriculum perpetuates the dominant ideologies of those in power as well as "their lacks of faith in the possibility that teachers can know and can also create" (Freire, 2005, p. 15). Freire (2005) suggests that packaged curricula cause teachers to be "enslaved by the packages themselves, domesticated by the teacher's guides, and limited in their adventure to create. Their autonomy and the autonomy of their schools are restrained from producing what the prepackaged practice promises: children who enjoy freedom, who are critical and creative" (p. $15)$.

Through opportunities in curriculum decision making and autonomy, teachers are able to criticize the presentation of educational discourse in schools and classrooms where values and social relations that produce and legitimate the dominant world view are perpetuated (Darder, 1991). Yet, in a scripted curriculum, teachers may find it difficult to

"challenge their students, through games, stories, and reading so that students understand the need to create coherence between discourse and practice: a discourse about the defense of the weak, of the poor, of the homeless, and a practice that forms the haves against the have-nots; a discourse that denies the existence of social classes, their conflicts, and a political practice entirely in favor of the powerful" (Freire, 1998, p. 15). 
When teachers engage their students in exploring these topics, they can make them aware of oppression, thus helping them to develop a sense of agency that engages students in the process of deconstructing the assumptions that perpetuate systems of oppression.

\section{Rejecting the Banking Method}

In order to reject the banking concept, teachers must present opportunities for students to construct knowledge and reinvent their world through delivering a curriculum that provides activities, texts, and a variety of learning experiences. Reinvention happens when teachers are responsive to the needs of students in order to create learning experiences that students connect to the exploration and understanding of their world (Darder, 2002). Again, research based curricular materials are not a detriment to teachers ability to construct lessons that are culturally relevant and inclusive. However, educators must be willing to transform the curriculum and the way that they teach and present information, so that it engages students and is connected to the real world. Freire (1987) states: "What we do in the classroom is not an isolated moment separate from the 'real world.' It is entirely connected to the real world" (p. 25). The connections to the real world provide authentic learning experiences that validate the whole person, who they are, what they bring to the classroom, culturally and linguistically, which can be used to stimulate student engagement and academic success.

Teachers should also help students understand and identify social issues and their role in change, while helping them engage in service projects where they are able to apply their knowledge as well as become "transformers of the world" (Freire, 2003). According to Freire, this would happen through students' ability to engage in posing questions to understand their reality and social issues. Problem posing education is a process in which teachers assist in the process of students grappling with issues connected to their reality (Darder, 2002), content, and learning experiences. Freire calls for a "problem-posing" discourse where together teachers and students use "authentic thinking" to engage with the curriculum and make sense of knowledge (Freire, 2003). When teachers engage in problem- posing education, the teacher first engages in his/her own process of deconstructing ideologies, which is brought to the classroom and the deconstructing process is continued with the students. Therefore, the entire class embarks on consciousness raising activities and exercises that stimulate the development of critical thinking skills. Teachers provide opportunities for students to question and make sense of the curriculum because there are opportunities for dialogue and lived experiences to be validated in the classroom. However, as teachers become more proficient at critically examining the curriculum, they realize that lived experiences are the starting point, not the end, of education. Without critical analysis, validation is as harmful as outright 
rejection because it fails to provide students with the skills that they need to critically analyze the world around them (Freire, 2003). The grappling process within the problem posing education gives teachers the opportunity to scaffold students' learning and differentiate instruction. Students are given tools to draw on the past, present, and future to make sense of their world (Darder, 2002).

However, teachers must see themselves as students and understand they are also engaging in the learning process. They should seek opportunities to understand the diverse cultures in their classroom so that they are able to employ best practices that validate students' linguistic abilities and culture. By understanding the cultures represented in the classroom, how lived cultures and realities are valued and articulated in the curriculum, or how teaching practices may suppress or affirm diverse students' understanding of their world, teachers are able to employ varied instructional approaches that address the diversity represented in the classroom (Darder, 1991). Finally, teachers need to acknowledge that through their own experience they make sense of world.

Within the scope of problem-posing education, teachers see students as active participants and use dialogue, inquiry, and analysis to generate and transmit knowledge. For some students, issues such as living in a single parent home, not having access to adequate health care, having responsibility for sibling because of a parent or guardians employment restriction, or being a migrant farm worker are valid experiences that contribute to knowledge construction. Students use these experiences while they engage in the process of making meaning and sense out of concepts learned in the classroom. This reconstruction of classroom experiences and the curriculum is based on their personal experiences.

In the process of reconstruction, teachers assist in the deconstruction of the curriculum, texts, and other materials to identify the reality of oppression as a closed world from which there is no exit and as a limiting situation which is transformed and used as the motivating force for liberating action (Freire, 2003). Teachers are able to assist in the critical examination of individual and societal roles in ways that are aligned to standards that support student achievement. As students and teachers interact with the curriculum through critical examination, they are able to uncover how domination and oppression are produced throughout the curriculum (Giroux, 1988).

\section{Teachers' Role in Curriculum Decision Making}

The system of high-stakes testing and standards based instruction in the federal government, state governments, and school districts exercise power over teachers through scripted curriculum (Darder \& Torres, 2004). We are in a time where teachers need to seek ways to empower themselves within the realm of their profession (Freire, 2003; Darder, 1991) by finding a voice in curriculum decision making. From a curricular standpoint, cultural exposure, as process of understanding, respecting, and affirming cultural differences, will enable teachers 
to become curriculum modifiers that actively engage in the deconstruction of dominant ideologies found in curriculum that may inadvertently affect their pedagogical approaches. "Teachers must recognize the manner in which scripted curriculum, high-stakes tests, and standards work to dis-empower both teachers and students in American public schools" (Darder, 1997, p. 332). In understanding this journey as a process, I believe that teachers will continuously raise student consciousness through curriculum development.

\section{High Stakes Testing}

High stakes testing is used to require accountability from the public school system for ensuring that all sub-groups of students are receiving a quality education. But Darder (1992) points out that "testing in schools historically has played an insidious role in the perpetuation of underachievement" (p. 3). Neito (1996) warns that "the validity and effects of tests are questionable, particularly for children from culturally and linguistically diverse backgrounds" (p. 91). The biases of standardized tests correlate with the cultural relevance and biases hidden in the language and question construction within the test (Darder \& Torres, 2004; Nieto, 1996; Darder 1991). Khon (1993) supports this argument against highstakes standardized testing in that he views this as a system of social control and regulation that seeks to reward some and punish others. Freire would challenge us to look at who the tests seek to empower or oppress and how they are used to sort so that some people are privileged and others not noting that testing is a means to "evaluate students not to enhance our practice but to punish them" (Freire, 2005, p. 13). Alfie Kohn (2000) argues against standardized testing in that:

"High-stakes testing has radically altered the kind of instruction that is offered in American schools, to the point that "teaching to the test" has become a prominent part of the nation's educational landscape. Teachers often feel obligated to set aside other subjects for days, weeks, or (particularly in schools serving low-income students) even months at a time in order to devote time to boosting students' test scores. Indeed, both the content and the format of instruction are affected; the test essentially becomes the curriculum" (p. 29).

Teaching and the curriculum is not about connecting the needs of the students, their lives, or experiences to the curriculum or infusing into instructional practices.

Banking education is a consequence of standardized testing in that "the emphasis of learning is transferred from intellectual activity to the dispensing of packaged fragments of information" (Darder \& Torres, 2004, p. 87). Moreover, they encourage "poor students not to be creators of knowledge but to be consumers of specific forms of knowledge" (Darder \& Torres, 2004, p. 91). High- 
stakes testing may appear to be critical to the social mobility of historically disadvantaged American public school students, while reproducing white middle and upper class hegemony. These hegemonic forces seek to preserve, codify, and measure success and learning instead of addressing dominant ideologies that seek to maintain cycles of poverty, crime, homelessness, and unemployment.

\section{Cultural Exposure}

When teaching in LCD communities, cultural exposure allows for teachers to see themselves as cultural workers (Freire, 2005). Teachers need to seek ways to understand the cultures represented in the classroom and understand how lived cultures and realities are valued and articulated in the curriculum or how teaching practices may suppress or affirm diverse students' understanding of their world (Darder, 1991). Culture has a variety of definitions and is understood in many ways by different theorist. The definition of culture I use comes from Antonia Darder's work. Culture is not devoid of power and there is an inherent relationship between culture and power. Therefore, culture is more than the knowledge, beliefs, art, morals, laws, and customs shared by members of a society (Darder, 1991).

Teachers are part of a system where they may not have the autonomy to create educational experiences that are liberating for themselves and their students, due to scripted or scripted curriculum choices. When teachers have engaged in consciousness raising opportunities they may seek opportunities to employ culturally relevant and inclusive pedagogies that will result in adapting or modifying the curriculum. For example, teachers may provide students with time to reflect on an assigned reading or text and consider how it connects to students' actual lives. Often times, teachers view themselves as oppressed, working in a system where they do not have autonomy to create educational experiences that are aligned to their values and beliefs about teaching and learning or acknowledge the linguistic and cultural diversity represented in their classrooms.

Reflection and dialogue, as a part of cultural exposure, can occur through interactions with peers and colleagues or reflective journaling. The overarching goal of the reflective process as part of cultural exposure is to help educators see and understand the multiple dimensions of their oppressive state as educators as well as the oppressive state of the students that they may serve. Humanization, as described by Freire (2003), begins with the recognition of dehumanization, which is part of the historical reality of the oppressed. Through dialogue, educators are able to identify the ways in which they are dehumanized by means of deprofessionalization and omission of the linguistic and cultural diversity of their students. Educators can be dehumanized as victims of injustice, exploitation, or oppression by the local or state systems, and federal mandates that have stolen teachers' ability to be appreciated as professionals. This process means engaging in the "struggle to abandon [their] dependency on traditional classroom artifacts" 
(Darder, 1997, p. 332). An example of this is the deconstruction of standards based curriculum to understand how it dictates what should be taught, how it should be taught, and when it should be taught. Teaching in a binding curriculum stifles teachers' creativity and professional abilities.

In order for teachers to be effective in reclaiming their own humanity or engagement in self-liberation, they can't assume the ideologies of oppressive forces, like administrators, standards, curriculum, and other state and federal mandates that influence how and what teachers teach. Teachers instead need to be restorers of their humanity through the liberation of themselves and their oppressors (Freire, 2003). However, in a system where dominant ideologies are perpetuated though multiple avenues such as teacher education programs, administrators, and curriculum, educators need to liberate themselves first, through critical reflection of their world views, beliefs, and values. Then, they can reflect on the curriculum because as educators, they have the greatest impact on how students interact with the curriculum and there may be beneficial consequences to this type of liberating teaching. Cultural exposure and reflection provides educators with the opportunity to discover ways that the curriculum stifles creativity and removes opportunities for individualized and differentiated instruction. Teachers then see ways that LCD students have been unjustly dealt with and deprived of their voices (Freire, 2003) within the context of curriculum planning.

Darder (2002) states that "students come into the classroom as a whole person and should be respected and treated as such" (p.98). Therefore, educators should seek appropriate pedagogical approaches to holistically integrate culture and language serve the students. Teachers engaging in cultural exposure may seek opportunities to understand the issues of the students and local community through engaging in meaningful conversations and dialogue with community members, parents, and students. Educators are no longer engaged solely in the fight for their own liberation as professionals, but also the fight for their students who are kept voiceless by an oppressive system (Freire, 2003). Without cultural exposure that provides an understanding of students' home and cultures, teachers cannot seek ways to validate the perceptions and experiences of LCD students (McLaren, 1989). Participating in the students' community is a way for teachers to gain a greater insight about the students' lives outside of school (Darder, 1991). Teachers are then in a position to see how power and politics go hand-in-hand to reinforce social inequalities which are demonstrated throughout the curriculum by engaging in a dialogue where knowledge is given and received by teachers, students, and families (Gonzalez, Moll, Amanti, 2005).

Teachers are able to see "culture as the lived experiences of students" (Gonzalez, Moll, \& Amanti, 2005, p. 40). When culture is ignored by teachers, students often find themselves trapped in classrooms that not only deny them a 
voice, but also deprive them of a relational or contextual understanding of how the knowledge they acquire in the classroom can be used to influence and transform the public sphere (Howell \& Tuitt, 2003). Teachers that are oblivious to the issues of the students' cultures and communities don't fully understand how students act and react to schooling and the curriculum, leaving culturally and linguistically diverse students to be stereotyped as underperforming, lazy, and a disruption to the learning of others. Instead, curriculum should be created to infuse aspects that are reflective of students' households and communities, by integrating how they use resources as a means to authentically engage students in the learning process.

Teachers should be able to collaborate with local businesses in the community as well as go to students' homes to talk to parents and learn more about the types of jobs they have to understand how that impacts the values and norms that students bring to the classroom. When educators commit the time and energy to become knowledgeable about the communities in which students live, they are able to understand the classroom communities better and provide a new frame of reference when approaching pedagogy (Darder, 1991). Teachers are able to incorporate the lived experiences and realities into the curriculum to provide an authentic opportunity for students to connect with the curriculum.

\section{Conclusion}

Darder and Torres (2004) state that "schooling practices reveal an ideology of domination that systematically reproduces, reinforces, and sustains the hegemonic forces of social control and regulation-forces linked to class oppression, gender, inequalities, and radicalized exclusion" (p. 78). Therefore, schools can be an oppressive system that serves to maintain a status quo. Within the standards based movement and high-stakes testing, teachers can seek ways to provide the best instructional opportunities for their students through cultural exposure and curriculum modification. School-home collaboration serves as a means for educators to understand the activities of household and social networks that contribute to students' ways of knowing (Gonzalez, Moll, Amanti, 2005). Cultural exposure moves teachers beyond their comfort zones to create holistic learning opportunities for all students.

Curriculum modification through cultural exposure is a process of deconstructing personal ideologies and philosophical beliefs that inform their practice, resulting in the creation of opportunities to explore, respect and affirm cultural differences and social and political implications in American society (Darder, 1991). Educators should be aware of the "hegemonic process of standardized testing" (Darder \& Torres, 2004, p.87) and how it has been constructed to make them accountable for "assuaging all the ills of society" (Freire, 2005, p. 7). In turn, educators will be encouraged through curricular autonomy to critically analyze curriculum and modify their curriculum so that 
they, along with students, are challenged to think critically about the curriculum and how educational ideologies are reflected in order to optimize student outcomes though effective instructional strategies.

Teachers engaging in curriculum modification through cultural exposure are able to create lessons that address the needs of LCD students. Teachers move away from recipes for classroom practices and engage in reflection and dialogue with colleagues, community members, parents, and students to create lessons that are not bound by the forced curriculum (Darder, 1997). Instead they draw on the linguistic abilities of students, their home experiences, their roles at home and at school to create lessons that align to the standards, hold the students to high expectations, and engage them in learning experiences that challenges students to question throughout the learning experience as well as find themselves represented in the curriculum. 


\section{References}

Allington, R.L. (2002). Big brother and the National Reading Curriculum: How ideology trumped evidence. Portsmouth: Heinemann.

Darder, A. (1991). Power and culture in the classroom. Westport: Bergin and Garvey.

Darder, A. (2002). Reinventing Paulo Freire: A Pedagogy of love. New York: Westview Press.

Darder, A., \& Torres, R. D. (2004). After race: Racism after multiculturalism. New York: New York University Press.

Darder, A., Torres, R.D., \& Gutierrez, H. (1997). Latinos and education: A critical reader. New York: Routledge.

Delpit, L. (1996). Other people's children: Cultural conflict in the classroom. New York: New Press.

Friere, P. (1970/2003). Pedagogy of the oppressed. New York: Continuum.

Freire, P. (2005). Teachers as cultural workers: Letters to those who to dare teach. Boulder: Westview Press.

Feire, P., \& Macedo, D. (1987). Literacy: Reading the word and the world. Boston: Bergin \& Garvey Publishers.

Gay, G. (1989). Ethnic minorities and educational equity. In J. A. Banks \& C. A. Banks (Eds.) Multicultural education: Issues and perspectives. (pp. 167188). Massechussets: Allyn and Bacon.

Giroux, H. (1992). Decentering the canon: Refiguring disciplinary and pedagogical boundaries. In Border crossings: Cultural workers and the politics of education (pp. 89-110). New York: Routledge.

Giroux, H. (1988). Teachers as intellectuals: Toward a critical pedagogy of learning: Bergin \& Garvey: New York.

Gonzalez, N., Moll, L.C. \& Amanti, C. (2005). Funds of knowledge. Mahwah: Lawrence Erlbaum Publishers.

Howell, A., \& Tuitt, F. (2003). Race and higher education: Rethinking pedagogy in diverse college classrooms. Harvard: Harvard Education.

Kayes, M., \& Maranto, R. (2006). A guide to charter schools: Research and practical advice for educators. New York: Rowman \& Littlefield.

Kohn, A. (1993). Punished by rewards. Boston: Houghton Mifflin.

Kohn, A. (2000). The case against standardized testing: Raising score, ruining schools. Portsmouth: Heinemann.

Ladson-Billings, G. (1994). The dreamkeepers: Successful teachers of AfricanAmerican children. San Francisco: Jossey-Bass.

Ladson-Billings, G. (1995). Towards a theory of culturally relevant pedagogy. American Education Research Journal, 32(3), 465-491.

Macedo, D. (2006). Literacies of power: What Americans are not allowed to know. New York: Westview Press. 
McLaren, P. (1989). Life in schools: An introduction to critical pedagogy in the foundations of education. New York: Longman.

McLaren, P., Farahmandpur, R. (2001). Educational policy and the socialist imagination: Revolutionary citizenship as a pedagogy of resistance. Educational Policy, 15, 343-378.

Nieto, S. (1996). Affirming diversity. New York: Longman Publishers.

Nieto, S. (1999). The light in their eyes: Creating Multicultural learning communities. New York: Teachers College Press.

Nieto, S. \& Bode, P. (2007). Affirming diversity: The sociopolitical context of multicultural education. New York: Allyn-Bacon.

Owings, W.A., Kaplan, L.S. (2001). Standards, retention and social promotion. National Association of Secondary School Principals. 629(85), 57-66.

Tomlinson, C.A. (Sept. 2000). Reconcilable differences? Standards -based teaching and differentiation. Educational Leadership. 7-11.

Samway, K. D., \& McKeon, K. (2007). Myths and realities: Best practices for English language learners. Porthsmouth: Heinemann. 